DOI 10.7764/rcia.v44i1.1709

RESEARCH PAPER

\title{
Extraction of Soluble Polysaccharides from Grape Skins
}

\author{
Mariona Gil Cortiella and Álvaro Peña-Neira \\ Universidad de Chile, Facultad de Ciencias Agronómicas, Departamento de Agroindustria y Enología. P.O. \\ Box 1004, Santiago, Chile
}

\begin{abstract}
A. Peña-Neira, M. Gil i Cortiella. 2017. Extraction of Soluble Polysaccharides from Grape Skins. Cien. Inv. Agr. 44(1): 83-93. Obtaining polysaccharides from grape cell walls is an interesting topic for the wine industry given its implications with regards to wine treatments and potential sensory attributes. In the present work, several conditions (i.e., a chelating agent, $\mathrm{pH}$, titratable acidity, extraction time, number of successive extractions, solid to liquid ratio and alcoholic fermentation) were tested to assess their effects on the yield of soluble polysaccharides obtained from grape skins. Among the four tested solvents (i.e., water, tartaric acid, ammonium oxalate, and ethylenediaminetetraacetic acid), aqueous ammonium oxalate was the most effective for polysaccharide extraction but also produced the highest amount of protein impurities. Increasing the number of successive extractions or modifying the extraction time does not increase the amount of total extracted polysaccharides but produces more polysaccharides with a low molecular mass. The extraction yield of polysaccharides does not increase by increasing the tartaric acid concentration; however, the extraction yield increases by increasing the $\mathrm{pH}$ of the solvent or decreasing the solid to liquid ratio during the extraction. During the fermentative maceration of the skins, the extraction of soluble polysaccharides is significantly higher than that obtained with aqueous solvents. Thus, it seems that grape skins contain some pectic polysaccharides that are tightly bound to the cell wall matrix that are not immediately solubilized by aqueous buffers and are released under alcoholic fermentation conditions.
\end{abstract}

Keywords: Carménère, extraction, grape skin polysaccharides, pectin, polysaccharides, wine.

\section{Introduction}

Plant cell walls have been a topic of great interest for a long time (Cleland, 1971; Somerville et al., 2004; Caffall and Mohnen, 2009). The scientific community has focused on understanding their structure, biosynthetic pathways, and functions

Received November 21, 2016. Accepted February 09, 2017. Corresponding author: apena@uchile.cl during the last few decades (Mohnen, 2008; Caffall and Mohnen, 2009; Gorshkova et al., 2013). Furthermore, it can be asserted that changes and structural modifications of plant cell walls during ripening, processing, and storage may severely affect the properties of fruit- and vegetable-based products (Kunzek et al., 1999; Rose and Bennett, 1999; Houben et al., 2011).

The properties of grape cell walls are a topic of great interest in the oenological field for several 
reasons. On the one hand, the cell walls of grapes have technological implications during winemaking, affecting parameters such as juice extraction and wine filterability (Vernhet and Moutounet, 2002; El Rayess et al., 2011). In addition, the structure and disassembly of grape skin cell walls strongly affect the phenolic extractability during red winemaking (Ortega-Heras et al., 2012; Quijada-Morín et al., 2015). On the other hand, the cell walls of grapes are the source of several soluble polysaccharides that are released during winemaking (Vidal et al., 2003; Guadalupe and Ayestarán, 2007); these polysaccharides, in turn, affect the final characteristics of wine, such as the colloidal stability, aromatic potential, and perception of astringency of wine (Waters et al., 1994; Dufour and Bayonove, 1999; Carvalho et al., 2006).

The most widely used methods for the characterization of grape skin cell walls were performed with cell walls isolated as the insoluble residue in ethanol (Hernández-Hierro et al., 2014; QuijadaMorín et al., 2015), as the insoluble residue in sodium deoxycholate-phenol-acetic acid-water (Lecas and Brillouet, 1994), or as the insoluble residue in 2-(4-(2-hydroxyethyl)piperazin-1-yl) ethane-1-sulfonic acid (HEPES) (Barnavon et al., 2000; Vidal et al., 2001; Doco et al., 2003; Ortega-regules et al., 2008; Apolinar-Valiente et al., 2010). However, only some of such works regard the soluble fraction of cell wall polysaccharides (Lecas and Brillouet, 1994; Vidal et al., 2001). The soluble fraction of grape cell walls is released from grape pomace to wine during winemaking; hence, the knowledge about the soluble polysaccharides contained in grapes and grape skins can be useful.

The present work examines the effect of several variables, such as the presence of a chelating agent, $\mathrm{pH}$, titratable acidity, extraction time, number of successive extractions, and the solid to liquid ratio in addition to the alcoholic fermentation of the soluble polysaccharides released from grape skins. These data could be interesting for maximizing polysaccharide extraction with characterization purposes but also to create a better understanding of the release of polysaccharides from grape skins during winemaking.

\section{Materials and methods}

\section{Chemicals and equipment}

Ammonium oxalate monohydrate and ammonium formate for HPLC $\geq 99.0 \%$ were purchased from Sigma-Aldrich (Sigma-Aldrich Co., St Louis, MO, USA), while the ethylenediaminetetraacetic acid disodium salt dihydrate (EDTA), hydrochloric acid fuming (37\%), and absolute ethanol used for analysis were purchased from Merck (Merck KGaA, Darmstadt, Germany). The tartaric acid was purchased from Drogueria Michelson (Drogueria Michelson, Santiago de Chile, Chile). Nine analytical standards for gel permeation chromatography (GPC) of dextrans from Leuconostoc mesenteroides (dextran 5000, dextran 12000, dextran 25000, dextran 50000, dextran 80000, dextran 150000, dextran 270000, dextran 410000 and dextran 670000) were used for column calibration Sigma-Aldrich (SigmaAldrich Co., St Louis, MO, USA). Two pectins, esterified potassium salts, from citrus fruit of different esterification degrees (55-70\% esterified and $20-34 \%$ esterified, respectively) were used as external standards for quantification (SigmaAldrich Co., St Louis, MO, USA).

The water purification system PURELAB Ultra (Elga Labwater, Arquimed, Santiago de Chile, Chile) was used for water purification. $\mathrm{pH}$ measurements were performed with a S220 Seven compact $\mathrm{pH} /$ Ion Mettler Toledo $\mathrm{pH}$-meter (Mettler-Toledo Intl. Inc., Columbus, OH, USA). Centrifugations were performed in a Heraeus Labofuge 400 Function line (Thermo Fisher Scientific Inc., Waltham, MA, USA). The orbital shaking platform used was a $\mathrm{MAX}^{\mathrm{Q}} 2000$ A-Class Barnstead Lab-Line (Thermo Fisher Scientific Inc., Waltham, MA, USA). A Heidolph type VV 
2000 rotary evaporator with a water bath of type WB 2000 (Heidolph Instruments GmbH \& Co., Schwabach, Germany) coupled to a Büchi V-700 vacuum pump (Cientec instrumentos científicos S.A., Santiago de Chile, Chile) was used for to concentrate the samples. An FD5508 Floor-Model Freeze dryer IlShin BioBase (Ilshin Biobase Co., LTD., Yangju-gun, South Korea) was used for sample lyophilization. High performance size exclusion chromatography-refractive index detection (HPSEC-RID) of soluble polysaccharides was performed using an Agilent 1260 Infinity Series liquid chromatograph (Agilent Technologies, Santa Clara, CA, USA) equipped with a G1329A autosampler, a G1311B quaternary pump, a G1316A column oven, a G1362A refractive index detector, and a G1315D diode array detector. The chromatograph was coupled to an Agilent Chem Station (version B.04.03) data-processing station.

\section{Grapes}

Grapes of the Vitis vinifera cultivar Carménère were obtained from a vineyard (self-rooted, planted in 2007) equipped with a drip irrigation system, at William Fevre Wineries in Pirque, in the Metropolitan Region of Chile (33'39'54' S and $\left.70^{\circ} 35^{\prime} 7^{\prime \prime} \mathrm{W}\right)$. They had been harvested on May 12,2014 , when the grapes reached approximately $24{ }^{\circ}$ Brix. The vines were trained on a double trellis system and arranged in rows spaced $2.5 \mathrm{~m}$ apart, with $2.0 \mathrm{~m}$ within the row. The estimated yield for the vintage was approximately 10 tons per ha. Harvested clusters were kept at $12{ }^{\circ} \mathrm{C}$ during transport to the laboratory and frozen at $-20{ }^{\circ} \mathrm{C}$ until analysis.

Procedure for the extraction of soluble polysaccharides from grape skins

The grapes were carefully destemmed and peeled by hand, maintaining a temperature of approximately $4{ }^{\circ} \mathrm{C}$. The obtained skins were mixed and distributed in batches of $5 \mathrm{~g}$ each. Every batch of grape skins was frozen with liquid nitrogen and ground to a fine powder by hand using a mortar and pestle. The extraction assays were performed in triplicate as follows:

Solvent assay. The skin homogenate $(5 \mathrm{~g})$ was placed in a centrifuge tube (50 mL capacity), and $30 \mathrm{~mL}$ of water, tartaric acid, ammonium oxalate or disodium EDTA aqueous solutions $\left(7.5 \mathrm{~g} \mathrm{~L}^{-1}\right.$ and adjusted to a $\mathrm{pH}$ of 7.5 with sodium hydroxide) was added. The tubes were placed on an orbital shaking platform (adjusted to $125 \mathrm{rpm}$ ) for $60 \mathrm{~min}$. Then, the tubes were centrifuged $(12,500 \cdot g$ for 20 $\mathrm{min}$ ), the pellets were discarded and the supernatant was used for the polysaccharide analysis.

Tartaric acid assay. This assay was performed as previously described using different solutions of tartaric acid as the solvent $(30 \mathrm{~mL}$ of solution per batch of $5 \mathrm{~g}$ of skin homogenate). Tartaric acid solutions were prepared with redistilled water at the following concentrations: $2.5 \mathrm{~g} \mathrm{~L}^{-1}$, $5.0 \mathrm{~g} \mathrm{~L}^{-1}$, and $7.5 \mathrm{~g} \mathrm{~L}^{-1}$. Each concentration was split in three aliquots. The first aliquot was used without any $\mathrm{pH}$ adjustment. The second and the third aliquots were adjusted to a $\mathrm{pH}$ of 3.5 and 7.5 , respectively, with sodium hydroxide.

Assay of extraction time. A $7.5 \mathrm{~g} \mathrm{~L}^{-1}$ solution of ammonium oxalate adjusted to a $\mathrm{pH}$ of 7.5 was used as the extraction solvent following the procedure described above $(30 \mathrm{~mL}$ of solution per batch of $5 \mathrm{~g}$ of skin homogenate) to test different times of contact between the skin homogenate and the extraction solvent in the orbital shaking platform (125 rpm). The following three lengths of contact time were tested: one, four and eighteen h. A fourth condition with multiple extractions was added to this assay as follows: $10 \mathrm{~mL}$ of the same ammonium oxalate solution was added to the $5 \mathrm{~g}$ of skin homogenate and placed in the orbital shaking platform (125 rpm) for $20 \mathrm{~min}$. Then, the samples were centrifuged (12500 $\mathrm{g}$ for $20 \mathrm{~min}$ ). The liquid was reserved, and the pellets were extracted again under the same conditions two more times. The three liquid fractions obtained 
after the successive extractions were pooled and used for the soluble polysaccharide analysis.

Assay of solid to liquid ratio. Five different solid to liquid ratios, 1:4, 1:6, 1:8, 1:10, and 1:20, were tested using ammonium oxalate $\left(7.5 \mathrm{~g} \mathrm{~L}^{-1}, \mathrm{pH}\right.$ of 7.5) as the extraction solvent following the same conditions described above. After the extraction, the samples were centrifuged (12500. $\mathrm{g}$ for $20 \mathrm{~min}$ ), the pellets were discarded and an aliquot of 25 $\mathrm{mL}$ of the supernatant was used for the soluble polysaccharide analysis.

\section{Micro-scale fermentations}

Micro-scale fermentations were performed to evaluate the extraction of the polysaccharides from the grape skins during the alcoholic fermentation. One liter of standard white grape juice concentrate (Jugos del Maipo, Santiago de Chile, Chile) was diluted with distilled water to $24^{\circ} \mathrm{Brix}$ and a $\mathrm{pH}$ of 3.4. Aliquots of $100 \mathrm{~mL}$ of the adjusted grape juice were placed in $250 \mathrm{~mL}$ Erlenmeyer flasks. Five $\mathrm{g}$ of skins from cv. Carménère grapes were added to the $100 \mathrm{~mL}$ of grape juice in triplicate, and triplicate samples without the skin addition were used as controls. Each flask was inoculated with $0.2 \mathrm{~g} \mathrm{~L}^{-1}$ of commercial yeasts (EC1118, Lallemand Inc., Montréal, Canada) and maintained at room temperature $\left(\sim 22^{\circ} \mathrm{C}\right)$ for $14 \mathrm{~d}$. The fermentation rates were monitored by loss of weight. Once the alcoholic fermentation was finished, the samples were centrifuged (12500 $\mathrm{g}$ for $20 \mathrm{~min}$ ), the pellets were discarded and the supernatant was used for the soluble polysaccharides analysis. The soluble polysaccharides released from the grape skins during fermentation were estimated by subtracting the control samples from the samples with the skin addition.

\section{Analysis of soluble polysaccharides}

The quantification of the soluble polysaccharides was performed by precipitation with acidified ethanol and a subsequent analysis by size exclusion chromatography (HRSEC-RID), as described by Fanzone et al. (2012). Briefly, $25 \mathrm{~mL}$ of a sample was concentrated five times (to a final volume of $5 \mathrm{~mL}$ ) with a rotary evaporator. The soluble polysaccharides were precipitated by the addition of $25 \mathrm{~mL}$ of acidified absolute ethanol (0.3 M hydrochloric acid) and maintained at 4 ${ }^{\circ} \mathrm{C}$ for $20 \mathrm{~h}$. Then, the samples were centrifuged (12500. $\mathrm{g}$ for $20 \mathrm{~min}$ ), the liquid was discarded and the pellets were washed three times with cold absolute ethanol. The precipitates were dissolved in $1 \mathrm{~mL}$ of redistilled water, frozen at $-80^{\circ} \mathrm{C}$ and lyophilized. The lyophilized samples were dissolved in $1 \mathrm{~mL}$ of $30 \mathrm{mM}$ ammonium formate and filtered through a $0.45 \mu \mathrm{m}$ pore size Millex-HV Hydrophilic PVDF membrane syringe filter (EMD Millipore, Billerica, MA). Finally, $100 \mu \mathrm{L}$ of the samples was injected into the chromatographic system. Separation was carried out using two Shodex OHpak SB-803 HQ and SB-804 HQ columns connected in a series (300 mm $\times 8$ mm I.D.; Showa Denko, Japan). The mobile phase consists of an aqueous solution of $30 \mathrm{mM}$ ammonium formate applied with a constant flow of $0.6 \mathrm{~mL} \mathrm{~min}^{-1}$ for $60 \mathrm{~min}$. The detection of polysaccharides was performed using a refractive index detector (RID). Along with the RID signal, the absorbance signal at $280 \mathrm{~nm}$ was recorded using a diode array detector (DAD) to estimate the amount of protein impurities. The molecular masses of the polysaccharide fractions were estimated by a comparison of the retention time with the commercial Dextran standards from Leuconostoc mesenteroides. The quantification of polysaccharides was performed according to the area of the peak using the external standard method with commercial pectins from citrus fruit as standards.

\section{Statistics}

All data are expressed as the arithmetic average \pm the standard deviation of a triplicate measurement. A one-way analysis of variance (ANOVA) 
was carried out with SPSS software (SPSS Inc., Chicago, IL), and multiple comparisons were performed using the Student-Newman-Keuls (S-N-K) post hoc test.

\section{Results and discussion}

According to the literature, several polysaccharides are easily solubilized in grape juice immediately after crushing and pressing the grapes (Vidal et al., 2000; Guadalupe and Ayestarán, 2007; Gao et al., 2015). Given that grape juice is an aqueous solution, redistilled water $\left(\mathrm{H}_{2} \mathrm{O}\right)$ should be an appropriate solvent for soluble polysaccharide extraction from grape skins. However, considering that grape juice also contains significant amounts of malate and tartrate, which are calcium chelating agents, and considering that such chelating agents could contribute to a higher extraction of polysaccharides by disrupting the Ca-bridges between pectin chains (Jarvis, 2011), an aqueous solution of tartaric acid $\left(\mathrm{H}_{2} \mathrm{~T}\right)$ was tested as an extraction solvent, even though it has not been previously described in the literature. In addition to $\mathrm{H}_{2} \mathrm{~T}$ and $\mathrm{H}_{2} \mathrm{O}$, the following most widely used chelating agents for pectin extraction were tested: ethylenediaminetetraacetic acid (EDTA) and oxalate (OX). $\mathrm{H}_{2} \mathrm{O}$ and $\mathrm{H}_{2} \mathrm{~T}$ do not show differences in polysaccharide extraction (Table 1) or their chromatographic profiles (Figure 1A and 1B); thus, it seems that, under our conditions, the chelating effect of tartrate is almost negligible. EDTA seems to favor the extraction of high molecular mass polysaccharides (F1, above 550 $\mathrm{KDa}$ ), although it does not extract greater amounts of smaller polysaccharides (F2 and F3, from 550 $\mathrm{KDa}$ to $20 \mathrm{KDa}$ and from $20 \mathrm{KDa}$ to $3 \mathrm{KDa}$, respectively) or total polysaccharides compared with $\mathrm{H}_{2} \mathrm{O}$ or $\mathrm{H}_{2} \mathrm{~T}$. In contrast, the extractions performed with OX show the highest amounts of F2, F3, and total polysaccharides compared to

Table 1. Extraction of soluble polysaccharides from grape skins cv. Carménère. F1: High molecular mass fraction (above $550 \mathrm{KDa}$ ); F2: Medium molecular mass fraction (between $550 \mathrm{KDa}$ and $20 \mathrm{KDa}$ ); F3: Low molecular mass fraction (between $20 \mathrm{KDa}$ and $3 \mathrm{KDa}$ ); TOTAL: total extracted polysaccharides. Different letters in each column indicate significant differences in polysaccharide extraction $(\mathrm{P} \leq 0.05)$ within a fraction for each assay.

\begin{tabular}{|c|c|c|c|c|}
\hline Solvent $\dagger$ & $\mathrm{F} 1$ & F2 & F3 & TOTAL \\
\hline $\mathrm{H}_{2} \mathrm{O}$ & $7.5 \pm 2.7 \mathrm{~A}$ & $107.8 \pm 11.2 \mathrm{~A}$ & $38.8 \pm 14.0 \mathrm{~A}$ & $154.1 \pm 27.8 \mathrm{~A}$ \\
\hline $\mathrm{H}_{2} \mathrm{~T}$ & $4.8 \pm 1.0 \mathrm{~A}$ & $106.1 \pm 2.5 \mathrm{~A}$ & $31.2 \pm 1.9 \mathrm{~A}$ & $142.0 \pm 3.4 \mathrm{~A}$ \\
\hline OX & $12.9 \pm 1.5 \mathrm{~B}$ & $235.0 \pm 33.0 \mathrm{~B}$ & $92.3 \pm 1.8 \mathrm{~B}$ & $340.2 \pm 29.8 \mathrm{~B}$ \\
\hline EDTA & $17.9 \pm 1.6 \mathrm{C}$ & $111.0 \pm 4.9 \mathrm{~A}$ & $52.1 \pm 0.1 \mathrm{~A}$ & $181.0 \pm 6.5 \mathrm{~A}$ \\
\hline $\mathrm{S} / \mathrm{L}+$ & $\mathrm{F} 1$ & $\mathrm{~F} 2$ & F3 & TOTAL \\
\hline $1: 4$ & $1.9 \pm 0.4 \mathrm{~A}$ & $166.7 \pm 20.5 \mathrm{~A}$ & $50.3 \pm 15.5 \mathrm{~A}$ & $225.0 \pm 34.6 \mathrm{~A}$ \\
\hline $1: 6$ & $11.4 \pm 3.3 \mathrm{~B}$ & $203.6 \pm 14.8 \mathrm{AB}$ & $52.1 \pm 4.7 \mathrm{~A}$ & $267.1 \pm 22.3 \mathrm{AB}$ \\
\hline $1: 8$ & $16.1 \pm 4.0 \mathrm{~B}$ & $209.9 \pm 35.3 \mathrm{AB}$ & $49.8 \pm 5.2 \mathrm{~A}$ & $275 \pm 43.2 \mathrm{AB}$ \\
\hline 1: 10 & $12.9 \pm 1.3 \mathrm{~B}$ & $177.4 \pm 25.2 \mathrm{AB}$ & $54.8 \pm 8.6 \mathrm{~A}$ & $241.4 \pm 40.0 \mathrm{AB}$ \\
\hline $1: 20$ & $18.2 \pm 1.9 \mathrm{~B}$ & $249.8 \pm 19.0 \mathrm{~B}$ & $69.4 \pm 4.1 \mathrm{~A}$ & $337.5 \pm 17.2 \mathrm{~B}$ \\
\hline Fermentation & $\mathrm{F} 1$ & $\mathrm{~F} 2$ & F3 & TOTAL \\
\hline CONTROL§ & $7.5 \pm 0.3 \mathrm{~A}$ & $303.9 \pm 4.5 \mathrm{~A}$ & $76.9 \pm 1.9 \mathrm{~A}$ & $388.4 \pm 5.5 \mathrm{~A}$ \\
\hline SKINS§ & $8.9 \pm 0.4 \mathrm{~B}$ & $358.8 \pm 4.4 \mathrm{~B}$ & $96.2 \pm 0.7 \mathrm{~B}$ & $463.9 \pm 3.7 \mathrm{~B}$ \\
\hline Skin extraction & $28.5 \pm 9.1$ & $1071.9 \pm 75.6$ & $370.4 \pm 19.9$ & $1470.9 \pm 66.3$ \\
\hline
\end{tabular}

$\uparrow$ Solvent assay. $\mathrm{H}_{2} \mathrm{O}$ : water. $\mathrm{H}_{2}$ T: tartaric acid. OX: ammonium oxalate. EDTA: ethylenediaminetetraacetic acid disodium salt. The results are expressed as $\mu \mathrm{g}$ of polysaccharides per $\mathrm{g}$ of grape skins.

$\ddagger$ Solid to liquid ratio during the extraction; the results are expressed as $\mu \mathrm{g}$ of polysaccharides per $\mathrm{g}$ of grape skins.

$\S$ Polysaccharides of finished micro-scale fermentations expressed as $\mathrm{mg} \mathrm{L}^{-1}$.

$\uparrow$ Polysaccharides extracted from grape skins during the alcoholic fermentation expressed as $\mu \mathrm{g} \mathrm{g}^{-1}$ of skin. 

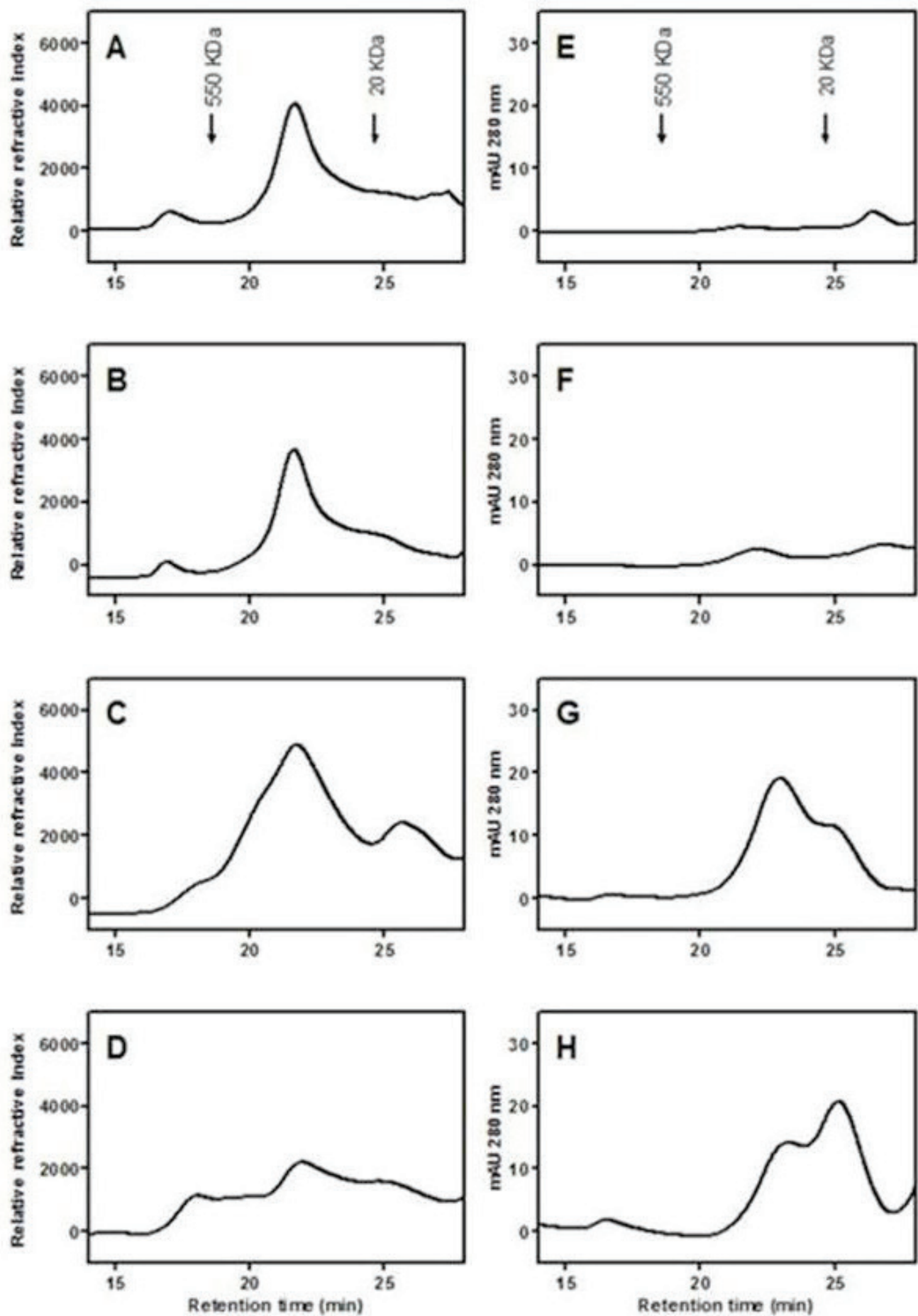

Figure 1. Left side plots: Chromatographic profiles (HRSEC-RID) of soluble polysaccharides extracted using different buffers: A: water; B: tartaric acid; C: ammonium oxalate; D: EDTA. Right side plots: Chromatographic profiles (HRSECDAD) recorded at $280 \mathrm{~nm}$ for the estimation of protein impurities extracted by using the buffers: E: water; F: tartaric acid; G: ammonium oxalate; H: EDTA. 
the other solvents. Thus, under our conditions, it seems that $\mathrm{OX}$ is the best solvent for soluble polysaccharide extraction from grape skins, although EDTA is the most effective solvent to extract high molecular mass polysaccharides. Our findings disagree with those reported by Silacci and Morrison (1990), who suggested that EDTA is much more effective than OX for pectin extraction, justifying mismatches in pectin extraction among different published studies. However, those studies used different grape materials and extraction conditions; thus, the substantial differences in polysaccharide extraction could not be attributed only to the chelating agent. OX and EDTA seem to extract more proteins than $\mathrm{H}_{2} \mathrm{O}$ and $\mathrm{H}_{2} \mathrm{~T}$ (Figure 1), although these signals could also be due to the protein domain of grape arabinogalactan-proteins (AGPs).

Since OX was the most effective solvent for polysaccharide extraction under our conditions, it was chosen as a solvent to assess the effect of extraction time. When the extraction time was extended beyond an hour, the extraction did not increase since the total quantity of extracted polysaccharides did not show significant differences among the samples extracted at 1, 4 and $18 \mathrm{~h}$ (Figure 2). However, F3 increased significantly with the maceration time. Thus, it seems that larger polysaccharides (F1 and F2) are quickly released, while some of the smallest polysaccharides (F3) remain in the skin homogenate and are continuously released when the extraction time is extended. Thus, it seems that a longer extraction time only affects the release of low molecular mass polysaccharides.

Several published studies extracted the grape material three times (Silacci and Morrison, 1990; Yakushiji et al., 2001; Deng et al., 2005; Zoccatelli et al., 2013). To test the effect of successive extractions (which avoid saturation effects of the solvent), a sample extracted after $1 \mathrm{~h}$ with $30 \mathrm{~mL}$ of OX (1 h, Figure 2) was compared with a sample extracted after $20 \mathrm{~min}$ with $10 \mathrm{~mL}$ of OX, repeated three times ( $1 \mathrm{~h}^{*}$, Figure 2$)$. Under these conditions, the total volume of the pooled extracts and the total time of extraction for $1 \mathrm{~h}^{*}$ are the same as those for $1 \mathrm{~h}$, despite the conditions differing in the solid to liquid ratio $(\mathrm{S} / \mathrm{L})$. The successive extractions did not increase the quantity of extracted polysaccharides, with the exception of F3, which is statistically higher for $1 \mathrm{~h}^{*}$ than for $1 \mathrm{~h}$. In fact, the amount of F1, F2 and total polysaccharides extracted for $1 \mathrm{~h}^{*}$ are even lower than those extracted for $1 \mathrm{~h}$. These results seem to indicate that, after the first step of the extraction, the grape homogenate maintains a reservoir of low molecular mass polysaccharides that could be released later, as also observed when the maceration time was extended.

To assess the effect of the S/L, OX was used as a solvent, and the $\mathrm{S} / \mathrm{L}$ ratios from 1:4 to $1: 20$ were tested (table 1). A lower S/L seem to favor the extraction of total polysaccharides since a statistical trend was observed for total extracted polysaccharides when the S/L decreases. Among the $S / L$ values tested, it seems that 1:20 reaches more soluble polysaccharides. This sample has an S/L close to that of the real winemaking conditions if we consider that the skins represent approximately $5 \%$ of the mass of a grape.

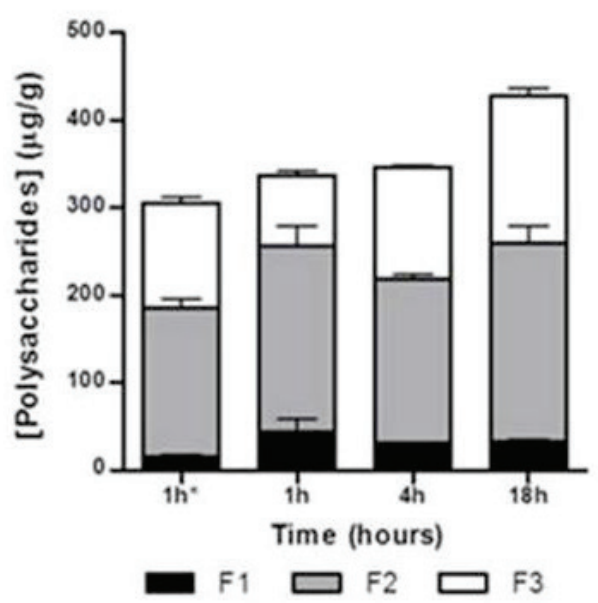

Figure 2. Effect of the extraction time on the concentration of soluble polysaccharides extracted from grape skins. F1: High molecular mass fraction (above $550 \mathrm{KDa}$ ); F2: Medium molecular mass fraction (between $550 \mathrm{KDa}$ and $20 \mathrm{KDa}$ ); F3: Low molecular mass fraction (between 20 $\mathrm{KDa}$ and $3 \mathrm{KDa})$. 
For a better understanding of the extraction of soluble polysaccharides in oenological conditions, the effects of both the $\mathrm{H}_{2} \mathrm{~T}$ concentration and the $\mathrm{pH}$ were tested (Figure 3 ). The extracted polysaccharides do not show any clear trend with respect to the tartrate concentration. In contrast, the extracted polysaccharides show a clear trend with the $\mathrm{pH}$ of the solvent as follows: the higher the $\mathrm{pH}$, the greater the extraction. The effect of $\mathrm{pH}$ on the polysaccharide extraction seems quite logical since, at higher $\mathrm{pH}$ values, the acid-base balance for tartaric acid leads to more carboxylate ions, which could capture $\mathrm{Ca}^{2+}$ ions, disrupting the Ca-bridges between pectin chains and favoring dissolution (Jarvis, 2011). These results suggest that the $\mathrm{pH}$ of grape juice could influence polysaccharide extraction from grape skins to grape juice.

Focusing again on the polysaccharide extraction under oenological conditions, micro-scale fermentations of white grape juice were performed in triplicate with and without the addition of 5\% grape skins (w/w) (these treatments were names "SKINS" and "CONTROL" respectively), that represent an S/L of 1:20. The concentration of polysaccharides of the SKINS wines is higher than that of the CONTROL wines (Table 1). Such differences could be attributed to the extraction of soluble polysaccharides from the grape skins (which corresponds to approximately $16 \%$ of the total amount of polysaccharides quantified in the SKIN samples); therefore, the skin extraction of polysaccharides per gram of grape skins during alcoholic fermentation can be calculated (skin extraction, Table 1). Alcoholic fermentation conditions enhance the extraction of polysaccharides from skins since the extraction (per gram of fresh grape skin basis) during alcoholic fermentation is 4-fold higher than the extraction with $\mathrm{OX}$ and approximately 10 -fold higher compared with $\mathrm{H}_{2} \mathrm{O}$ or $\mathrm{T}_{2} \mathrm{H}$. According to the literature, after an initial solubilization of polysaccharides during the crushing and pressing of grapes (Vidal et al., 2000), additional grape polysaccharides are released from the pomace into the wine during red wine fermentation (Doco et al., 1996; Guadalupe
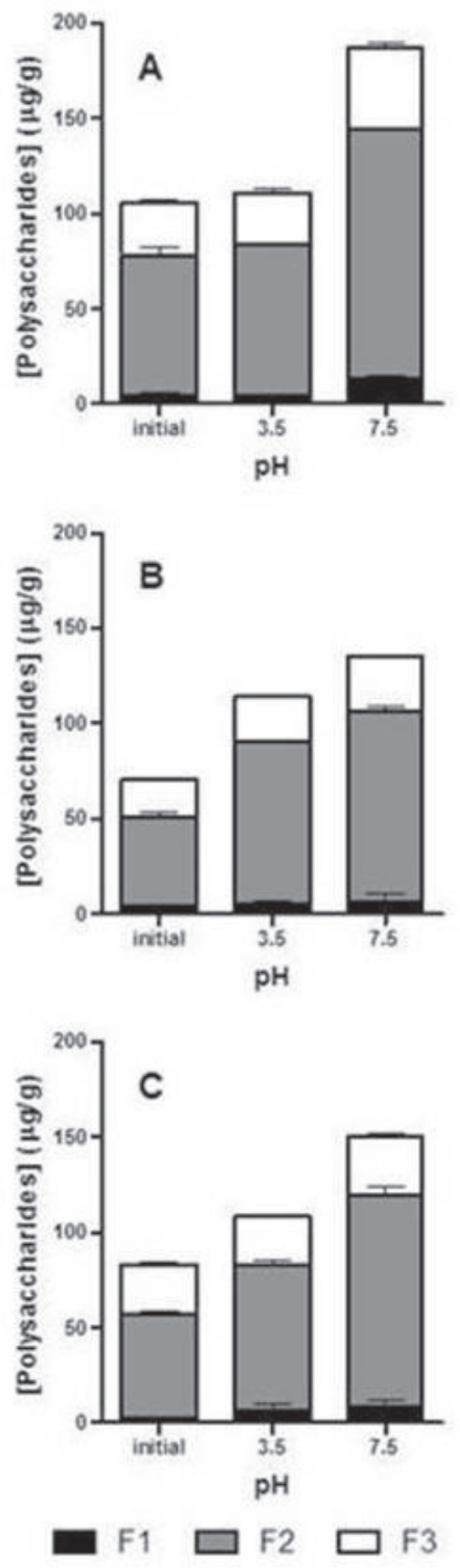

Figure 3. Soluble polysaccharide extraction from grape skins cv. Carménère using different concentrations of tartaric acid adjusted at different $\mathrm{pH}$ values. A: $2.5 \mathrm{~g} \mathrm{~L}^{-1}$ of tartaric acid; B: $5.0 \mathrm{~g} \mathrm{~L}^{-1}$ of tartaric acid. C: $7.5 \mathrm{~g} \mathrm{~L}^{-1}$ of tartaric acid. Initial $\mathrm{pH}$ values correspond to $2.37,2.28$ and 2.25 for $2.5 \mathrm{~g} \mathrm{~L}^{-1}, 5.0 \mathrm{~g} \mathrm{~L}^{-1}$ and $7.5 \mathrm{~g} \mathrm{~L}^{-1}$, respectively). F1: High molecular mass fraction (above $550 \mathrm{KDa}$ ); F2: Medium molecular mass fraction (between $550 \mathrm{KDa}$ and $20 \mathrm{KDa}$ ); F3: Low molecular mass fraction (between 20 $\mathrm{KDa}$ and $3 \mathrm{KDa})$. 
and Ayestarán, 2007; Gil et al., 2015). This later solubilization may be due to the action of chelating agents present in the grape juice but also due to modifications of the grape cell wall that occur as a consequence of the fermentation process and the activities of several enzymes (Zietsman et al., 2015). Moreover, fermentative maceration is delayed for two weeks, while the tested extractions with chelating agents take just one hour. Therefore, it seems logical that the extraction of soluble polysaccharides from grape skins under fermentative conditions was greater than the extraction obtained using aqueous solvents. Further work will be required to establish the relationship between the soluble polysaccharides of grape skins at harvest and the final concentration of cell wall-derived polysaccharides in the finished wines.

Given the results obtained, the following conclusions are proposed: Ammonium oxalate is the most effective solvent to extract soluble polysaccharides from grape skins (cv. Carménère) among the four solvents tested in this assay. Increasing the extraction time or the number of successive extractions only increased the content of polysaccharides with a lower molecular mass. Lower solid to liquid ratios seem to favor the extraction of soluble polysaccharides from grape skins. When tartaric acid was used as an aqueous solvent, the extracted polysaccharides increased with $\mathrm{pH}$, while no clear trend was observed by increasing the tartaric acid concentration (from $2.5 \mathrm{~g} \mathrm{~L}^{-1}$ to $\left.7.5 \mathrm{~g} \mathrm{~L}^{-1}\right)$. During the fermentative maceration of red winemaking, the extraction of soluble polysaccharides from grape skins (which corresponds to approximately $16 \%$ of the total polysaccharides of the final wine) is significantly higher than the extraction obtained with aqueous solvents. Thus, it seems that grape skins contain some pectic polysaccharides tightly bound to the cell wall matrix that are released during the fermentative maceration of during the making of red wine. These results allow a better understanding of the effect of the factors studied on the extractability of polysaccharides from grape skins.

\section{Acknowledgements}

This work was supported by CONICYT-Chile (FONDECYT postdoctoral project number 3150322 and FONDECYT grant number 1140882). The authors would like to thank American Journal Experts for proofreading the manuscript and providing help with language. The authors would also like to thank Dr. Carla Jara for kindly providing the grape juice concentrate, Dr. Claudio Pastenes for the use of the lab facilities, and Dr. Víctor Escalona for providing the lyophilizer.

\title{
Resumen
}

\begin{abstract}
A. Peña-Neira, M. Gil i Cortiella. 2017. Extracción de polisacáridos solubles procedentes de hollejos de uva. Cien. Inv. Agr. 44(1): 83-93. El interés acerca de los polisacáridos del vino procedentes de las paredes celulares de la uva ha ido en aumento, debido principalmente a sus implicaciones tecnológicas y sensoriales. A pesar de ello, todavía hay un gran desconocimiento acerca de cuáles son los factores que tienen más incidencia sobre la solubilización de estos compuestos desde la uva hacia el vino. Por ello, en el presente trabajo se ha estudiado el efecto de factores como el pH, la acidez, la relación sólido-líquido, el tiempo de extracción, los agentes quelantes o la fermentación alcohólica sobre la liberación de polisacáridos de hollejos de uva de la variedad Carménère. Los resultados obtenidos indican un incremento de la extracción de polisacáridos al aumentar el pH y al disminuir la relación sólido-líquido. Además, incrementando el tiempo de extracción o el número de extracciones tan sólo se observa un incremento de los polisacáridos de baja masa molecular, lo que parece indicar que los polisacáridos de mayor tamaño se solubilizan de forma rápida, y que después
\end{abstract}


de la extracción inicial, las partes sólidas conservan un reservorio de polisacáridos de baja masa molecular que se pueden ir solubilizando posteriormente. La extracción de polisacáridos de los hollejos durante la fermentación alcohólica es muy superior a la extracción de dichos compuestos desde los hollejos durante procesos de extracción no fermentativos, lo que constata las modificaciones que sufren las paredes celulares de los hollejos durante la fermentación alcohólica. Dichas modificaciones parecen favorecer claramente la extracción de polisacáridos desde los hollejos hacia el vino.

Palabras clave: Carménère, extracción, pectinas, polisacáridos solubles, uva, vino.

\section{References}

Apolinar-Valiente, R., I. Romero-Cascales, J.M. López-Roca, E. Gómez-Plaza, and J.M. RosGarcía. 2010. Application and comparison of four selected procedures for the isolation of cellwall material from the skin of grapes cv. Monastrell. Anal. Chim. Acta 660(1-2):206-210.

Barnavon, L., T. Doco, N. Terrier, A. Ageorges, C. Romieu, and P. Pellerin. 2000. Analysis of cell wall neutral sugar composition, b-galactosidase activity and a related cDNA clone throughout the development of Vitis vinifera grape berries. Plant Physiol. Biochem. 38(4):289-300.

Caffall, K.H., and D. Mohnen. 2009. The structure, function, and biosynthesis of plant cell wall pectic polysaccharides. Carbohydr. Res. 344(14):1879-1900.

Carvalho, E., N. Mateus, B. Plet, I. Pianet, E. Dufourc, and V. De Freitas. 2006. Influence of wine pectic polysaccharides on the interactions between condensed tannins and salivary proteins. J. Agric. Food Chem. 54(23):8936-8944.

Cleland, R. 1971. Controlling cell wall extension. Annu. Rev. Plant Physiol. 229: 458.

Deng, Y., Y. Wu, and Y.F. Li. 2005. Changes in firmness, cell wall composition and cell wall hydrolases of grapes stored in high oxygen atmospheres. Food Res. Int. 38(7):769-776.

Doco, T., J.-M. Brillouet, and M. Moutounet. 1996. Evolution of grape (Carignan noir cv.) and yeast polysaccharides during fermentation and postmaceration. Am. J. Enol. Vitic. 47(1):108-110.

Doco, T., P. Williams, M. Pauly, M.A. O'Neill, and P. Pellerin. 2003. Polysaccharides from grape berry cell walls . Part II . Structural characterization of the xyloglucan polysaccharides. Carbohydr. Polym. 53:253-261.

Dufour, C., and C.L. Bayonove. 1999. Influence of wine structurally different polysaccharides on the volatility of aroma substances in a model system. J. Agric. Food Chem. 47(2):671-677.

Fanzone, M., A. Peña-Neira, M. Gil, V. Jofré, M. Assof, and F. Zamora. 2012. Impact of phenolic and polysaccharidic composition on commercial value of Argentinean Malbec and Cabernet Sauvignon wines. Food Res. Int. 45(1):402-414.

Gao, Y., J.U. Fangel, W.G.T. Willats, M. a. Vivier, and J.P. Moore. 2015. Dissecting the polysacchariderich grape cell wall changes during winemaking using combined high-throughput and fractionation methods. Carbohydr. Polym. 133:567-577.

Gil, M., M. Quiros, F. Fort, P. Morales, R. Gonzalez, J.-M. Canals, and F. Zamora. 2015. Influence of grape maturity and maceration length on polysaccharide composition of Cabernet sauvignon red wines. Am. J. Enol. Vitic. 66(3):393-397.

Gorshkova, T. a, L. V Kozlova, and P. V Mikshina. 2013. Spatial structure of plant cell wall polysaccharides and its functional significance. Biochem. 78(7):836-53.

Guadalupe, Z., and B. Ayestarán. 2007. Polysaccharide profile and content during the vinification and aging of Tempranillo red wines. Carbohydr. Polym. 55(26):10720-10728.

Hernández-Hierro, J.M., N. Quijada-Morín, L. Martínez-Lapuente, Z. Guadalupe, B. Ayestarán, J.C. Rivas-Gonzalo, and M.T. Escribano-Bailón. 2014. Relationship between skin cell wall composition and anthocyanin extractability of Vitis vinifera L. cv. Tempranillo at different grape ripeness degree. Food Chem. 146(1):41-7. 
Houben, K., R.P. Jolie, I. Fraeye, A.M. Van Loey, and M.E. Hendrickx. 2011. Comparative study of the cell wall composition of broccoli, carrot, and tomato: Structural characterization of the extractable pectins and hemicelluloses. Carbohydr. Res. 346(9):1105-1111.

Jarvis, M.C. 2011. Plant cell walls: Supramolecular assemblies. Food Hydrocoll. 25(2):257-262.

Kunzek, H., R. Kabbert, and D. Gloyna. 1999. Aspects of material science in food processing: changes in plant cell walls of fruits and vegetables. Zeitschrift für Leb. und -forsch. A 208(4):233-250.

Lecas, M., and J.-M. Brillouet. 1994. Cell wall composition of grape berry skins. Phytochemistry 35(5):1241-1243.

Mohnen, D. 2008. Pectin structure and biosynthesis. Curr. Opin. Plant Biol. 11(3):266-277.

Ortega-Heras, M., S. Pérez-Magariño, and M.L. González-Sanjosé. 2012. Comparative study of the use of maceration enzymes and cold prefermentative maceration on phenolic and anthocyanic composition and colour of a Mencía red wine. LWT - Food Sci. Technol. 48(1):1-8.

Ortega-regules, A., J.M. Ros-García, A.B. BautistaOrtín, J.M. López-Roca, and E. Gómez-Plaza. 2008. Changes in skin cell wall composition during the maturation of four premium wine grape varieties. J. Sci. Food Agric. 88(December 2007): 420-428.

Quijada-Morín, N., J.M. Hernández-Hierro, J.C. RivasGonzalo, and M.T. Escribano-Bailón. 2015. Extractability of Low Molecular Mass Flavanols and Flavonols from Red Grape Skins. Relationship to Cell Wall Composition at Different Ripeness Stages. J. Agric. Food Chem. 63(35): 7654-7662.

El Rayess, Y., C. Albasi, P. Bacchin, P. Taillandier, J. Raynal, M. Mietton-Peuchot, and A. Devatine. 2011. Cross-flow microfiltration applied to oenology: A review. J. Memb. Sci. 382(1-2):1-19.

Rose, J.K.C., and A.B. Bennett. 1999. Cooperative disassembly of the cellulose-xyloglucan network of plant cell walls: Parallels between cell expansion and fruit ripening. Trends Plant Sci. 4(5):176-183.

Silacci, M., and J. Morrison. 1990. Changes in pectin content of Cabernet Sauvignon grape berries during maturation. Am. J. Enol. Vitic. 41(2):111115.

Somerville, C., S. Bauer, G. Brininstool, M. Facette, T. Hamann, J. Milne, E. Osborne, A. Paredez, S. Persson, T. Raab, S. Vorwerk, and H. Youngs. 2004. Toward a systems approach to understanding plant cell walls. Science (80-). 306(December):2206-2212.

Vernhet, A., and M. Moutounet. 2002. Fouling of organic microfiltration membranes by wine constituents: importance, relative impact of wine polysccharides and polyphenols and incidence of membrane. J. Memb. Sci. 201(1-2):103-122.

Vidal, S., T. Doco, M. Moutounet, and P. Pellerin. 2000. Soluble polysaccharide content at initial time of experimental must preparation. Am. J. Enol. Vitic. 51(2):115-121.

Vidal, S., P. Williams, T. Doco, M. Moutounet, and P. Pellerin. 2003. The polysaccharides of red wine: total fractionation and characterization. Carbohydr. Polym. 54(4):439-447.

Vidal, S., P. Williams, M.A. O'Neill, and P. Pellerin. 2001. Polysaccharides from grape berry cell walls. Part I: Tissue distribution and structural characterization of the pectic polysaccharides. Carbohydr. Polym. 45(4):315-323.

Waters, E.J., P. Pellerin, and J. Brillouet. 1994. A Wine Arabinogalgactan-protein That Reduces Heat-induced Wine Protein Haze. Biosci. Biotechnol. Biochem. 58(1):43-48.

Yakushiji, H., N. Sakurai, and K. Morinaga. 2001. Changes in cell-wall polysaccharides from the mesocarp of grape berries during veraison. Physiol. Plant. 111(2):188-195.

Zietsman, A.J.J., J.P. Moore, J.U. Fangel, W.G.T. Willats, J. Trygg, and M.A. Vivier. 2015. Following the compositional changes of fresh grape skin cell walls during the fermentation process in the presence and absence of maceration enzymes. J. Agric. Food Chem. 63(10):2798-2810.

Zoccatelli, G., S. Zenoni, S. Savoi, S. Dal Santo, P. Tononi, V. Zandonà, a. Dal Cin, V. Guantieri, M. Pezzotti, and G.B. Tornielli. 2013. Skin pectin metabolism during the postharvest dehydration of berries from three distinct grapevine cultivars. Aust. J. Grape Wine Res. 19(2):171-179. 